\title{
Studi Terhadap Kosakata Bahasa Arab Dalam Bahasa Minangkabau
}

\author{
Akhyar Hanif \\ Institut Agama Islam Negeri (IAIN) Batusangkar \\ akhyarhanif68@gmail.com
}

\begin{abstract}
Abstrak
Tulisan ini berusaha mengungkap pengaruh bahasa Arab terhadap bahasa Minangkabau, dan berusaha mencari hubungan antar bahasa tersebut. Kedudukkan bahasa Arab sebagai bahasa al-Qur'an sebagai bahasa kitab suci, kemudian berkembang dan menyebar hampir ke seluruh wilayah dan negeri di dunia ini seiring berkembangnya agama Islam ke berbagai daerah termasuk Minangkabau. Sejarah pun membuktikan bahwa bahasa Arab memiliki pengaruh yang sangat besar dalam perkembangan kosakata dalam bahasa Minangkabau. Oleh karena itu, tulisan ini mencoba menelusur kosakata bahasa Arab yang masuk dalam Minangkabau. Kajian ini membuktikan bahwa ada lebih dari 500 kosakata Minangkabau yang merupakan serapan dari bahasa Arab, dan tentunya kajian ini akan lebih panjang lagi jika diteliti lebih jauh dari setiap daerah yang ada di Minangkabau.
\end{abstract}

Kata kunci: Studi kosakata, bahasa Arab, bahasa Minangkabau

\begin{abstract}
This paper seeks to reveal the influence of Arabic on Minangkabau language, and trying to find relationships between these languages. Constitute Arabic as the language of the Qur'an as the language of scripture, then expand and spread almost to all regions and countries in this world as the development of Islam to various regions including Minangkabau. History also proves that Arabic has a very big influence in the development of vocabulary in Minangkabau language. Therefore, this paper tries to trace the Arabic vocabulary that goes into Minangkabau. This study proves that there are more than 500 Minangkabau vocabulary which is the absorption of Arabic, and of course this study will be much longer if examined further from every area in Minangkabau.
\end{abstract}

Keywords: Vocabulary study, Arabic, Minangkabau language 


\section{Pendahuluan}

Bahasa Arab telah mendapat kehormatan besar, bahasa ini sengaja dipilih Allah Swt. untuk menjadi bahasa kitab suci-Nya al-Qur'an. ${ }^{1}$ Dipilihnya bahasa Arab sebagai bahasa al-Qur'an tentu tidak berarti bahwa ia diperuntukkan hanya bagi orang-orang Arab. Kedudukkan bahasa Arab sebagai bahasa al-Qur'an lebih bersifat teknis penyampain pesan dari pada masalah nilai. Artinya, penggunaannya sebagai bahasa kitab suci adalah wujud khusus dari ketetuan umum bahwa Allah tidak mengutus seorang Rasul pun kecuali dengan bahasa kaumnya. ${ }^{2}$ yakni, masyarakat yang menjadi audience langsung seruan rasul itu dalam menjalankan misi sucinya. Dalam hal Nabi Muhammad Saw. kaumnya itu ialah masyarakat Arab, khususnya masyarakat Makkah dan sekitarnya. ${ }^{3}$

Pandangan yang menyatakan bahwa kedudukan bahasa Arab sebagai bahasa al-Qur'an lebih merupakan soal teknis penyampaian pesan dari pada soal nilai ditunjang oleh keterangan al-Qur'an itu sendiri, yaitu keterangan bahwa karena Nabi Muhammad Saw. adalah orang Arab maka mustahil Allah mewahyukan ajaran-Nya dalam bahasa bukan-Arab. Perhatikan ayat berikut: Artinya;

Seandainya Kami jadikan ia (kitab suci) ini Qur'an yang berbahasa bukan-Arab, tentu mereka (orang-orang kafir) itu akan berkata, "Kalau saja ayat-ayatnya itu dirinci (dijelaskan secar rinci)." Apakah (mungkin sebuah kitab suci dalam bahasa) bukan-Arab, sedangkan dia (Nabi Mubammad) seorang Arab? Katakan (hai Mubammad), "Dia (kitab suci) itu merupakan petunjuk dan obat bagi mereka yang beriman. Sedangkan mereka yang tidak beriman itu, pada telinga mereka ada sumbat, dan ada kebutaan pada (mata) mereka. Mereka itu seolab-olah mendapat panggilan dari tempat yang jaub (sebingga tidak mendengar dan tidak menyadari).(QS.41:44)

Di samping itu, terdapat pula kejelasan bahwa ternyata penggunaan bahasa Arab sebagai bahasa al-Qur'an tidak semata-mata karena alasan teknis penyampaian pesan. Ia terkait erat dengan doktrin tentang kemukjizatan al-

\footnotetext{
${ }^{1}$ Banyak ayat yang secara eksplisit menyebutkan hal itu seperti; إنا تنزلناه قرآنا عربيا لعلم تعقلون \{ يوسف 12: Sesungguhnya Kami telah menurunkannya berupa al-Qur'an dengan berbahasa Arab agar kalian memahaminya). Hal serupa dapat pula dilihat dalam ayat-ayat berikut; QS. 42:7, QS. 16:103, QS. 26:195, QS. 13:37, QS. 20:113, QS. 39:28, QS. 41:3, QS. 43:3, 46:12.

${ }^{2}$ Lihat QS. 14:4 yakni; "Dan Kami tidak pernah mengutus seorang Rasul pun melainkan dengan bahasa kumnya, supaya ia dapat memberi penjelasan dengan terang kepada mereka...".Al-Qur'an dan Terjemahannya, h. 379

${ }^{3}$ Lihat QS. 6:92 yakni; “Dan ini (al-Qur'an) adalah kitab yang telah Kami turunkan yang diberkahi; membenarkan kitab-kitab yang (diturunkan) sebelumnya dan agar Engkau (Muhammad) memberi peringatan kepada (penduduk) ibukota (Makkah) dan sekitarnya...". Al-Qur'an dan Terjemahannya, h. 202
} 
Qur'an yang tidak dapat ditiru oleh manusia. Salah satu kemukjizatan al-Qur'an itu ialah ekspresi puitisnya yang sangat khas dan unik. Kekhasan dan keunikan itu berkat digunakannya medium bahasa Arab. Dengan kata lain, ekspresi puitis yang khas dan unik itu seakan punya kekuatan metafisis yang aneh pada para pendengarnya. Ekspresi puitis yang khas dan unik itu dengan sendirinya akan hilang manakala bahasa mediumnya dipindah atau ditukar dengan bahasa selain bahasa Arab. ${ }^{4}$

Argumen berikut barangkali dapat pula menunjang mengapa bahasa ini dipilih Allah untuk menjadi bahasa bagi kitab suci-Nya. Bahasa Arab itu adalah bahasa yang unik, mempunyai keistimewaan-keistimewaan tersendiri dan sekaligus kaya dengan kosakata dibanding bahasa-bahasa lain. Di antara keunikan dan kekayaan bahasa Arab tersebut bukan saja terlihat pada jenis kelamin kata atau bilangannya yaitu tunggal (mufrad), dual (mutsanna) dan (jamak) atau plural, tetapi juga pada kekayaan kosakata dan sinonimnya. Sebagai contoh, kata yang bermakna tinggi -misalnya- mempunyai enam puluh sinonim. Kata yang bermakna singa bersinonim 500 kata, ular sinonimnya 200 kata. Kata (عل) yang berarti madu ditemukan sebanyak 80 kata. Sedang kata yang menunjuk kepada aneka pedang ditemukan sebanyak lebih kurang 1000 kata. Kata yang menunjuk kepada unta dan keadaannya 5.644 kata. Bahkan ada sementara pakar berpendapat bahwa terdapat 25 juta kosakata bahasa Arab. ${ }^{5}$

Dalam kapasitasnya sebagai bahasa kitab suci, bahasa Arab kemudian berkembang dan menyebar hampir ke seluruh wilayah dan negeri di dunia ini. Perkembangan dan penyebaran bahasa ini tentu sejalan dengan berkembang dan tersebarnya Islam itu sendiri. Sebagaimana diketahui, dalam sejarah Islam disebutkan bahwa semasa Rasulullah Saw. masih hidup, hampir seluruh Jazirah Arabia telah tunduk di bawah kekuasaan Islam. Ekpansi Islam ke daerah-daerah di luar Jazirah Arabia pun telah dimulai meski belum menampakkan hasil. Ekspansi tersebut kemudian dilanjutkan oleh khalifat rasûlillah. Khalifah pertama, Abu Bakar al-Siddiq (632-634 M) misalnya, melanjutkan pengiriman pasukkan yang dipimpin oleh Usamah untuk menghadapi pasukkan Romawi di bagian utara. ${ }^{6}$ Demikian halnya dengan Khalifah kedua, Umar Ibn al-Khattab (634-644

${ }^{4}$ Sekedar hendak memberi contoh cobalah "rasakan" ekspresi puitis tersebut dengan membaca, misalnya, surat al-Âdiyât/100 dan kemudian coba ganti dengan bahasa atau kosakata lainnya lalu rasakan betapa bedanya. Lihat Nurcholish Madjid, Islam Doktrin dan Peradaban: Sebuah Telaah Kritis Tentang Masalah Keimanan, Kemanusian dan Kemodernan, (Jakarta: Yayasan Wakaf Paramadina, 1995), Cet.3, h.364-365

${ }^{5}$ Untuk mengetahui lebih jauh dan rinci bagaimana keunikan dan keistimewaan bahasa Arab sebagai bahasa al-Qur'an dapat dilihat dari uraian Muhammad Quraish Shihab dalam bukunya, Mukjizat al-Qur'an: Ditinjau Dari Aspek Kebahasaan, Isyarat Ilmiah dan Pemberitaan Gaib, (Bandung: Mizan, 2003), Cet. XIV, h. 96

${ }^{6}$ Ibn Atsir, Al-Kâmil fi al-Târîkh, (Bairut: Dâr al-Sader, 1965), h. 334 
M). di masanya kota Damaskus jatuh ke pangkuan Islam (th. 635 M) lalu menyusul pula Iraq dan Mesir. ${ }^{7}$

Penyebaran Islam dilanjutkan oleh Khalifah ketiga, Usman ibn Affan (644-656 M) dan dan keempat, Ali ibn Abi Thalib (656-661 M). Sepeninggal Ali, Mu'awiyah tampil dengan dinastinya Bani Umayah (661-750) dan ekpansi gelombang kedua terjadi di zaman dinasti ini. ${ }^{8}$ Dinasti Umayah diganti oleh dinasti Abbasiyah (750-1258 M). Di masa dinasti Abbasiyah inilah Islam mencapai puncak keemasannya (the Golden Age). Islam pada masa itu telah meluas melalui Afrika Utara sampai ke Spayol di Barat dan melalui Persia sampai ke India Timur. Daerah-daerah tersebut tunduk kepada khalifah yang berkedudukan di Madinah kemudian di Damsyik dan kemudian di Bagdad.'

Tersebarnya ajaran Islam ke seluruh penjuru dunia berimplikasi tersebarnya bahasa Arab. Oleh karena itu, menurut A.F.L Beeston, banyak negara, hingga kini, menyatakan bahwa bahasa resmi negara mereka adalah bahasa Arab, seperti negara Maroko, Aljazair, Tunis, Libya, Republik Persatuan Arab, Sudan, Libanon, Syiria, Jordan, Irak, dan beberapa negara di semenanjung Arabia. Sedangkan negara-negara yang tidak berbahasa Arab ialah orang-orang Barbar di Afrika Utara (kebanyakan dari mereka mempergunakan bahasa Arab dan Barbar). Bangsa yang berbahasa Kurdi (yaitu dialek Iran) yang terletak di Irak Utara. Sebagian bangsa Syiria dan juga bangsa pengembara dari Sudan Selatan. Di luar mereka, bahasa Arab dipergunakan di Israel dan Barat Laut Iran dan di beberapa daerah yang dikelilingi oleh negeri asing, Republik Central Asia di Uni Soviet (dahulu) dan juga di beberapa wilayah selatan sahara. ${ }^{10}$

Demikianlah terlihat sekilas bagaimana proses ekspansi Islam ke seluruh penjuru dunia termasuk ke bumi Nusantara. Dalam konteks Nusantara, menurut Azyumardi Azra, hubungan antara kaum muslimin di kawasan Melayu-Indonesia dan Timur Tengah telah terjalin sejak masa-masa awal Islam. Para pedagang muslim dari Arab, Persia dan anak Benua India yang mendatangi kepulauan Nusantara tidak hanya berdagang, tetapi dalam batas tertentu juga menyebarkan Islam kepada penduduk setempat. ${ }^{11}$

${ }^{7}$ Harun Nasution, Islam Ditinjau Dari Berbagai Aspeknya, (Jakarta: UI Press, 1985), h. 57

${ }^{8}$ Ibid, h. 58

${ }^{9}$ Harun Nasution, Pembaruan Dalam Islam: Sejarah, Pemikiran dan Gerakan, (Jakarta:Bulan Bintang, 1975), h. 13

${ }^{10}$ A.F.L Beeston, The Arabic Language Today, (London:Huchinso \& Co, 1970), h. 11

11 Dalam seminar yang diselenggarakan pada tahun 1969 dan 1978 tentang kedatangan Islam ke Indonesia para ahli Indonesia menyimpulkan, Islam datang langsung dari Arabia, tidak dari India, tidak pada abad 12 atau 13 melainkan dalam abad pertama Hijriyah atau abad ke-7. Akan tetapi proses Islamisasi di Indonesia nampaknya baru 


\section{Bahasa Arab sebagai Bahasa “Agama”}

Setiap komunitas bahasa hampir pasti mengklaim bahwa hanya bahasanya yang terbaik, orang-orang Cina akan mengatakan bahwa bahasa Cinalah yang terbaik, demikian pula orang Ibrani, orang Yunani dan lain sebagainya. Bangsa Arab juga demikian mengklaim bahwa bahasa Arab adalah bahasa terbaik di antara bahasa-bahasa lain di dunia. ${ }^{12}$ Bahkan tak tanggungtanggung mereka menyanjung-nyanjung bahasa ini dengan sesuatu yang sulit diterima akal sehat. Seperti contoh berikut ini, diriwayatkan oleh Ibn 'Asakir dari Ibn Abbas, bahwa sesungguhnya Nabi Adam a.s. mengerti bahasa Arab, ketika dia berada di sorga dahulu maka bahasa yang digunakannya adalah bahasa Arab, akan tetapi ketika dia durhaka maka Tuhan mencabut bahasa ini darinya, kemudian dia berbicara dengan bahasa Suryaniyah, setelah dia bertobat maka Allah mengembalikan lagi padanya kemampuan berbahasa Arab ini. ${ }^{13}$

Tentu saja kita sangat sulit menerima argumen ini karena tidak saja susah untuk dibuktikan secara empirik tetapi juga sangat sulit dicerna dengan akal sehat, lebih dari itu, argumen yang tidak masuk akal ini terkesan mengada-ada dan bersifat apologik.

Oleh sebagian orang muslim, termasuk di Indonesia, bahasa Arab ini dianggap sebagai bahasa yang sakral seperti sakralnya kitab suci al-Qur'an. Menurut mereka, karena bahasa ini tidak saja telah dipilih Tuhan menjadi bahasa kitab-Nya melainkan juga bahasa ini "wajib" dipergunakan ketika melaksanakan ritual-ritual keagamaan, terutama dalam pelaksanaan ritus-ritus yang bersifat ta'abbudi. Sepanjang menyangkut bahasa al-Qur'an, terdapat kesepakatan bulat di kalangan orang-orang Islam, bahwa al-Qur'an tidak disebut al-Qur'an lagi manakala bahasanya diganti dengan bahasa selain bahasa Arab, sungguh pun itu sinonim dari kata-katanya. Oleh karena itu, terjemahan tidak dapat menggantikan kedudukan kitab ini dalam bahasa aslinya. Konsep seperti ini tidak berlaku dalam kitab-kitab suci lainnya.

Sementara itu, pangalaman empirik menunjukkan bahwa penggunaan bahasa Arab dalam tindakan-tindakan formal keagamaan, seperti dalam ritusritus tadi, memberi rasa kesatuan sedunia tersendiri (universal). Meski terdapat

mengalami akselarasi pada abad ke-12 dan ke-16. Sejauh menyangkut teori-teori kedatangan dan berekembangnya Islam di Nusantara, banyak teori yang dikemukakan para pakar. Dengan rinci dan kritis hal tersebut telah dilacak dan diuraikan secara mendalam oleh Azyumardi Azra, Jaringan Ulama Timur Tengah dan Kepulauan Nusantara Abad XVII dan XVIII: Melacak Akar-akar Pembaruan Pemikiran Islam di Indonesia, (Bandung: Mizan, 1995), Cet. 3, h. 17, 30-31

${ }^{12}$ Klaim seperti hampir kita dapat dalam setiap penulis Arab antara lihat, Ibrahim al-Samirra'i, Fiqh al-Lughah al-Muqâran, (Bairut: Dar al-Ilmi Li al-Malayin, 1987, h. 7-8

${ }^{13}$ Al-Suyuthi, al-Muzhir fi Ulûmi al-Lughah wa Anwâ 'ihâ, jilid I. h. 30 
kontroversi menyangkut hal ini; seperti pengalaman Turki di masa silam yang mengganti lafaz-lafaz az̧an dan iqâmat dengan bahasa Turki. Belakangan, terjadi pula di salah satu kota di pulau jawa, di mana sekolompok orang mencoba menerjemahkan bacaan al-fatibah, dalam pelaksanaan ritual sholat, ke dalam bahasa Indonesia. Menurut mereka, dengan diterjemahkannya lafaz-lafaz shalat itu ke dalam bahasa Indonesia dalam pelaksanaan shalat, membuat shalat mereka semakin khusu' dibanding dengan membacanya dalam bahasa aslinya, karena kebanyakan masyarakat tidak mengerti bahasa Arab. Kejadian ini sempat pula menghebohkan masyarakat muslim Indonesia.

Terlepas dari itu semua, memang sebaiknya keseragaman bacaan dalam pelaksanaan ritus-ritus keagamaan itu tetap dipertahankan. Akan tetapi, hal ini dilakukan dengan tetap adanya keharusan memahami secara kognitif makna dari bacaan yang dibaca. Sebab jika tidak, maka suatu ritus tidak lagi berfungsi sebagai sarana penghayatan ajaran yang benar, tetapi dapat berubah menjadi sejenis matra yang magis, suatu hal yang bertentangan dengan keseluruhan semangat Islam berdasarkan Tauhid yang berimplikasi antara lain pembebasan manusia dari takhayul dan mitologi. Di sinilah pentingnya mempelajari bahasa Arab, agar kita dapat mengerti dengan baik kandungan al-Qur'an, tentu juga sunnah Nabi Saw, dan semangat ajarannya secara keseluruhan.

Selanjutnya, ada beberapa pertanyaan mendasar yang mesti dijelaskan di sini sejauh menyangkut kedudukan bahasa Arab dan kaitannya dengan agama Islam. Apakah bahasa Arab identik dengan al-Qur'an? Bukankah bahasa ini hanya alat untuk penyampaian pesan Tuhan? Apakah sama antara ke-Islam-an dan ke-Arab-an?

Dalam konteks ini menarik disimak ulasan Cak Nur sebagai berikut: Secara historis, terdapat pandangan di kalangan banyak orang, baik yang muslim maupun yang bukan, tentang kesejajaran antara "ke-Islam-an" dan kearaban "ke-Arab-an". Tetapi dalam tela'ah lebih lanjut, pandangan itu nampak didasarkan lebih banyak kepada kesan daripada kenyataan. Sebab kenyataannya ialah bahwa bahasa Arab bukanlah bahasa khusus orang-orang muslim dan agama Islam, melainkan juga bahasa kaum non-muslim dan agama bukan Islam seperti Yahudi dan Kristen. Minoritas-minoritas bukan Arab yang non-muslim sampai sekarang masih tetap bertahan di seluruh dunia Arab, termasuk Jazirah Arabia, kecuali kawasan yang kini membentuk kerajaan Arab Saudi, lebih khusus lagi provinsi Hijaz (Makkah-Madinah). Bahkan orang-orang Kristen Libanon adalah keturunan langsung Banu Ghassan yang sudah terkristenkan lama sejak sebelum Rasulullah Saw. Yaitu sejak mereka menjadi satelit kerajaan Romawi yang telah memeluk agama Kristen sejak raja Konstantin.

Begitu pula bahasa Arab bukanlah satu-satunya bahasa Islam. Ketika orang-orang Arab muslim Arab melakukan ekspansi militer dan politik keluar 
jazirah Arabia, mereka membawa agama Islam kepada masyarakat bukan Arab. Memang sebagian besar bangsa-bangsa itu akhirnya mengalami arabisasi, yang di zaman modern ini menghasilkan kesatuan budaya dan kawasan sosial-politik Liga Arab. Persia atau Iran pun, khususnya Khurasan, juga pernah mengalami pengaraban. Tetapi kemudian pada bangsa ini tumbuh gerakan nasionalisme yang disebut syu'übiyah, dan bahasa Persi dihidupkan kembali dengan penuh semangat. Namun hasilnya adalah sebuah "bahasa Persi Islam" yaitu sebuah bahasa yang masih kukuh mempertahankan sintaks dan gramatika Persi sebagai suatu bahasa Indo-Eropa tapi dengan kosakata yang didominasi oleh pinjaman dari bahasa Arab, serta dengan muatan ideologis yang bersumber dari ajaran Islam. Lebih dari itu, bahasa Persi kemudian tampil sebagai alat menyatakan pikiran-pikiran Islam yang tidak kalah penting dari bahasa Arab, jika bukannya dalam beberapa hal malah lebih penting (seperti dalam bidang tasawuf, filsafat, dan teori-teori pemerintahan atau politik).

Disebabkan oleh peranan bahasa Persi, maka sesungguhnya Dunia Islam dapat dibagi menjadi dua; pertama, ialah kawasan pengaruh bahasa Arab, yaitu "Dunia Arab" seperti yang dikenal dewasa ini, dan, kedua, kawasan pengaruh bahasa Persi yang meliputi seluruh wilayah Islam bukan-Arab, khususnya Persia atau Iran sendiri, kemudian Afghanistan, Transoxiana, anak-Benua IndoPakistan dan Turki, yang secara racial stock umumnya Eropa kebetulan juga terdiri dari bangsa-bangsa Indo-Eropa, bukan Semitik. Meskipun daerah-daerah selain Iran itu mempunyai bahasa-bahasa mereka sendiri, namun bahasa-bahasa itu amat terpengaruh oleh bahasa Persi dan banyak membuat pinjaman dari bahasa itu.

Disamping kedua daerah budaya Arab dan Persi itu, ada beberapa kawasan atau lingkungan Dunia Islam lainnya dengan corak budaya tertentu dan ditandai oleh dominasi bahasa tertentu. Salah satunya yang harus kita sebut ialah kawasan Asia Tenggara dengan ciri dominasi bahasa Melayu/Indonesia. Tetapi Bahasa Melayu/Indonesia pun cukup berat mendapatkan pengaruh dari bahasa Persi berupa pinjaman banyak kosakata Persi itu yang berasal dari bahasa Arab. Petunjuk besarnya pengaruh bahasa Persi itu dapat ditemukan pada kenyataan pergantian hampir semua $t a^{\prime}$ marbûthah menjadi ta' maftuhah, seperti pada katakata adat, dawat, darurat, firasat, harakat, isyarat, laknat, masyarakat, mufakat, qiraat, salat, siasat, taat, warkat, zakat, dan lain-lain. Begitulah adanya, meskipun ada juga sedikit kata-kata Melayu/Indonesia dengan akhiran ta' marbûthah yang menunjukkannya sebagai pinjaman langsung dari bahasa Arab tanpa melalui 
bahasa Persi, seperti kata-kata bid'ah, gairah, marah, (dari am-mârah), makalah, nuktah, risalah, zarrah dan lain-lain. ${ }^{14}$

Oleh karena itu, Islam yang bersifat universal itu, yang berlaku di semua tempat dan waktu, tidak boleh dihambat atau tergantung kepada suatu bentuk formalisme tertentu, termasuk di dalamnya formalisme bahasa. Al-Qur'an sendiri menegaskan bahwa ia diturunkan untuk seluruh umat manusia. Karena Nabi Muhammad Saw. memang diutus Tuhan untuk semua manusia. ${ }^{15}$ Ini berarti bahwa ajaran Islam itu berlaku bagi bangsa Arab dan bangsa-bangsa nonArab dalam tingkat yang sama. Dari sudut pandang itulah kita dapat mengerti penjelasan, baik dari al-Qur'an maupun hadis-hadis Nabi Saw, bahwa segi kebahasaan, begitu pula kebangsaan, tidak relevan dengan universlisme Islam. Oleh karena itu, kita dapat mengerti pesan Nabi misalnya "tidak ada kelebiban seorang Arab atas seorang non-Arab selain dengan taqwa"16. Semakna dengan itu, kita temukan pula firman Allah dalam al-Qur'an (QS. Al-Hujurât 49:13), "Sesunggubnya yang paling mulia di antara kamu di hadapan Allah adalah paling bertaqwa"17

Dalam konteks ini pulalah kita mengerti pesan Tuhan mengenai perbedaan bahasa, dan perbedaan warna kulit, hanyalah merupakan tanda-tanda kebesaran atau ayat-ayat Allah semata. Seperti ditegaskan dalam firman-Nya: "Dan di antara tanda-tanda (kebesaran)-Nya ialah penciptaan langit dan bumi serta perbedaan bahasa-bahasamu sekalian dan wama-warna (kulit)-mu sekalian. Sesunggubnya dalam hal yang demikian itu terdapat tanda-tanda bagi mereka yang berpengetahuan" (QS.al-Rûm 30:22). ${ }^{18}$ Maka sebagai tanda kebesaran Tuhan, suatu bahasa, termasuk bahasa Arab, memberi petunjuk tentang kemahakuasaan Sang Maha Pencipta, yaitu Allah, tanpa nilai intrinsik dalam bahasa itu sendiri. Dengan kata lain, kedudukan semua bahasa adalah sama di sisi Allah.

\section{Kontak Bahasa Arab Dengan Bahasa Minangkabau}

Paling tidak terdapat dua teori besar menyangkut kedatangan Islam ke Minangkabau, pertama kita sebut saja teori Tiku dan kedua teori Siak. Azyumardi Azra misalnya, mengatakan konversi Minangkabau ke dalam Islam

${ }^{14}$ Nurcholish Madjid, Islam Doktrin dan Peradaban: Sebuah Telaah Kritis Tentang Masalah Keimanan, Kemanusian dan Kemodernan, (Jakarta: Yayasan Wakaf Paramadina, 1995), Cet.3, h.359-360

${ }^{15}$ Diantara ayat yang berbicara mengenai ini adalah (QS. Al-A'raf 7:158). Yang bunyinya adalah: قل يايها الناس إنى رسول الله إليكم جميعا (katakan 'hai Muhammad'; wahai seluruh manusia! Sesungguhnya aku adalah utusan Allah untuk kamu semua).

لا فضل لعربى على أعجمى إلا بالتقوى

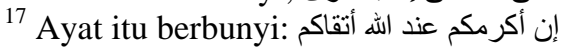

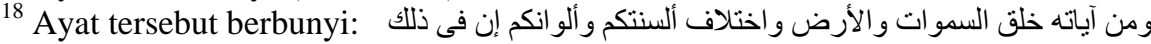
لآيات للعالمين (QS.al-Rûm 30:22 
tampaknya dimulai sekitar abad ke-16 dan terjadi melalui baik sungai Pesisir Barat maupun Pesisir Timur. Pelabuhan terkenal bagi perdagangan Pesisir Barat kaum Muslim Arab dan India yang berasal dari Gujarat mempunyai peranan penting khususnya dalam penyebaran Islam di kalangan penduduk Minangkabau. Tiku, pelabuhan utama bagi perdagangan saat itu, diislamisasikan menjelang dekade kedua abad ke-16. ${ }^{19}$ Para pejabat administarasi dan pelabuhan semuanya bergelar muslim, dan guru-guru Islam yang mengetahui dengan baik ayat-ayat al-Qur'an adalah di antara bukti-bukti yang tersedia di pelabuhan. Konversi Pariaman dan Ulakan kemudian menyusul, khususnya setelah terbentuknya kontrol Aceh atas Pesisir Barat. Menurut Van Ronkel, seperti yang dikutip Azyumardi Azra, menegaskan bahwa Tiku dan Pariaman merupakan jalur yang dijadikan jalan masuk Islam ke wilayah pedalaman Sumatera. Teori ini sesuai dengan ungkapan adat Minangkabau yang berbunyi "syara" mandaki adat manurun", artinya; syara' (hukum Islam) mendaki (dari Pesisir), sedangkan adat menurun (dari gunung Merapi). Sebagaimana diyakini umumnya oleh orang Minang, bahwa Islam diperkenalkan dari Pesisir Barat ke wilayah Darek. ${ }^{20}$

Akan tetapi Hamka, juga mengemukakan teori kedatangan Islam di Minangkabau, dia menunjukkan bahwa Islam telah mencapai wilayah darek jauh lebih awal melalui pesisir timur Sumatera. Ia menegaskan bahwa perpindahan keluarga kerajaan ke daerah Buo-Sumpur Kudus, dan keterlibatannya dalam perdagangan emas di Selat Malaka, menimbulkan hubungan dengan istana kerajaan Malaka yang telah diislamkan pada abad ke-15. Sultan Malaka, Mansyur Syah, yang meninggal tahun 1475, adalah penguasa Kampar dan Indiragiri di Riau. Ini mengakibatkan masuk Islamnya para penguasa di tempat-tempat ini, dan menjadi lebih penting bagi siapa pun -termasuk orang Minang- untuk berhubungan dengan istana yang telah diislamkan, setidaknya untuk menjalankan transaksi dagang dengan menggunakan para pedagang dan juru tulis muslim. ${ }^{21}$

Dalam tulisannya yang lain, tanpa menyebutkan sumber-sumbernya, Hamka menyebutkan bahwa yang mula-mula datang membawa Islam ke Minangkabau ialah seorang yang datang dari Gujarat bernama Labai Panjang Janggut, ia datang melalui sungai Siak dan membawa serta beberapa orang penduduk negeri Siak, hingga dia sampai dan menetap di Galogadang, Luhak

${ }^{19}$ Azyumardi Azra, Surau: Pendidikan Islam Tradisional Dalam Transisi dan Modernisasi, (Jakarta: Logos Wacana Ilmu, 2003), Cet.1, h. 42 (selanjutnya disebut Azyumardi Azra, Surau...) bandingkan dengan Sanusi Latif, Gerakan Kaum Tua DiMinangkabau, (Jakarta: Disertasi IAIN Jakarta, 1988), h. 44-45

${ }^{20}$ Ibid, h. 42

${ }^{21}$ Hamka, Sedjarah Islam di Sumatera, (Medan: t.p., 1950), h. 11 bandingkan juga dengan Ismail Ja'kub, Sejarah Islam Di Indonesia, (Djakarta: t.p, 1956), h. 22 
Tanah Datar. Itulah sebabnya kemudian para ahli agama di Minangkabau disebut "Labai" dan para pelajar agama disebut "urang siak".

Bagaimanapun, terlepas dari perdebatan tentang proses awal islamisasi Minangkabau ini, abad ke-16 itu merupakan periode yang sangat penting dalam sejarah Minangkabau, karena mencakup institusionalisasi Islam dalam struktur sosial Minangkabau. Menjelang akhir abad ke-17, proses islamisasi berkembang lebih cepat dan Islam telah menegakkan jejak kakinya yang kokoh sepanjang Pesisir Sumatra Barat. Mejelang pertengahan abad ke-17, semua pusat perdagangan dan perkampungan dengan bagian terbesarnya adalah pedagang di antara para penduduknya telah masuk ke dalam Islam. Sumpur Kudus menjadi terkenal sebagai "Makkahnya daerah darek" dan pusat-pusat perdagangan lain, seperti Talawi dan Padang Ginting juga menjadi muslim, begitu pula pusat awal Hindu-Budha di sekitar Suruaso dan Pagaruyung mungkin berkonversi ke dalam Islam ketika keluarga kerajaan kembali ke sana. ${ }^{23}$

Faktor masuknya raja alam Pagaruyung juga kemudian ikut andil juga dalam mempercepat proses islamisasi di Minangkabau, di samping faktor-faktor lainnya. Akan tetapi perlu diingat bahwa ketika Sultan Alif ini memerintah kekuasan raja Minangkabau ini tidak sebesar kekuasaan raja-raja Islam di pulau Jawa. Karena bentuk pemerintahannya tidak bersifat sentaralistik tetapi lebih berbentuk desentaralistik. Oleh karena itu, meski raja itu dihormati oleh rakyatnya sedemikian rupa akan tetapi posisinya tidak lebih sebagai symbol belaka. Hal lain yang juga perlu ditegaskan bahwa kerajaan Islam Pagaruyung tersebut tidak mempunyai angkatan perang yang kuat seperti Aceh, Banten, Demak dan lain-lain. Nagari-nagari dikuasai oleh penguasa-penguasa (penghulupenghulu) yang bersifat independen mengatur dirinya sendiri. ${ }^{24}$

Menurut Azyumardi Azra, bahwa Islam yang tersebar di Minangkabau pada masa-masa awal konversi Minangkabau ke dalam Islam adalah Islam buah karya para sufi Tarekat, karena dalam keseluruhan penafsiran mereka atas Islam sangat sesuai dengan latar belakang Minangkabau yang banyak dipengaruhi oleh singkretisme Hindu-Budha dan tradisi setempat. Sufi tarekat dalam banyak kasus memang sangat toleran terhadap pemakaian dan pemikiran tradisional yang bertentangan dengan utilitarianisme praktik Islam yang ketat (yang sering disebut dengan syariah oriented). Karena itu cukup beralasan jika orang menganggap bahwa karakter Islam pada masa awal-awal tersebut lebih bersifat singkretis dan mistis. ${ }^{25}$ Pada abad ke-18, di Minangkabau terdapat dua pusat

${ }^{22}$ Hamka, Minangkabau Dengan Islam, (Bukittinggi: t,p., 1929), h. 10

${ }^{23}$ Christine Dobbin, Islamic Revivalism In Changing Peasant Economy Central Sumatera, 1774-1848, (London: Curson Press Ltd, 1983), h. 119-120

${ }^{24}$ MD. Mansoer Dkk, Sejarah Minangkabu, (Jakarta: Bhratara, 1970), h. 63

${ }^{25}$ Azyumardi Azra, Surau... Op.cit., h. 44 
tarekat besar, yakni Ulakan dan Cangking. Ulakan, aliran tarekat yang dipegang adalah tarekat Syattariyah yang dikembangkan oleh Syeikh Burhanuddin dan murid-muridnya. Syeikh ini pernah belajar ke Aceh dengan seorang guru yang bernama Abdurrauf al-Singkel. Sementara di Cangking (Ampat Angkat, Agam) yang berkembang adalah tarekat Naqsabandiyah. Tarekat ini dipimpin oleh Tuanku Nan Tuo Cangking yang pernah juga berguru kepada seorang ulama yang pernah berguru di Ulakan, kepada Syaikh Burhanuddin sendiri, yaitu Tuanku Nan Tuo di Mansiangan. Oleh karena saking hebatnya pertentangan antara para pengikut kedua tarekat ini di Minangkabau, maka terkenallah dalam sebutan lidah orang Minangkabau: "Agama Cangking dan Agama Ulakan".

Pada abad-abad selanjutnya terjadilah perkembangan Islam yang cukup signifikan di bumi Minangkabau. Bahkan negeri ini disebut-sebut sebagai negeri paling awal yang mengadakan pergerakan pembaharuan Islam di Indonesia, dan memainkan peranan sangat penting dalam penyebaran ide-ide pembaharuan Islam ke wilayah-wilayah lain di Nusantara. ${ }^{27}$ Gerakan pembaharuan itu ditandai dengan pulangnya putra-putra Minangkabau, di permulaan abad ke-19 (tahun 1802 ${ }^{28}$, yang telah belajar di pusat-pusat Islam, seperti Mekkah, Madinah, dan belakangan, juga dari Kairo. ${ }^{29}$ Dinamika internal masyarakat Minangkabau yang mengakui konflik sebagai hal esensial untuk memperoleh integrasi sosial menjadikan daerah ini sebuah tempat penting gerakan pembaharuan Islam sejak masa awal gerakan Paderi yang sangat terkenal itu.

Bagaimanapun, adalah fakta yang tak terbantahkan, bahwa Islam telah terserap dan menyatu sedemikian rupa ke dalam semua aspek kehidupan

${ }^{26}$ Hamka, Ayahku: Riwayat DR. H. Amrullah dan Perjuangan Kaum Agama di Sumatera, (Jakarta: Umminda, 1982), Cet-IV, h.

${ }^{27}$ Hamka, Muhammadiyah di Minangkabau, (Jakarta: t, p., 1974), h. 7

${ }^{28}$ M.D. Mansoer dkk, Sedjarah Minangkabau, (DJakarta:Bhratara, 1970), h. 67, menyebutkan bahwa kepulangan tiga haji itu dari Mekkah tahun 1803

${ }^{29}$ Tiga ulama yang pulang dari Mekkah pada tahun (1802) itu adalah Haji Miskin di Pandai Sikek (Luhak Agam), Haji Abdur Rahman di Piobang (Luhak Lima Puluh Kota), dan Haji Muhammad Arif di Sumanik (Luhak Tanah Datar). Yang terakhir dikenal juga dengan sebutan "Tuanku Lintau" sebab beliau berpindah dari Sumanik ke Lintau, dalam Luhak Tanah Datar juga. Lihat Hamka, Ayahku, Op.cit., h. 14. Gerakan pembaharuan itu kemudian berlanjut dan bahkan semakin intens pada permulaan abad ke-20, dengan kembalinya empat orang ulama Minangkabau, setelah mereka mendalami ilmu pengetahuan dan mendapat gemblengan dari syaikh Ahmad Khatib, mereka itu ialah, Syaikh Abdullah Ahmad, Syaikh Jamil Jambek, Syaikh Abdul Karim Amrullah dan Syaikh M. Thaib Umar. Lihat Sanusi Latief, Op.cit., h. 64 yang disebut takhir adalah guru dari Mahmud Yunus yang kemudian sempat Melanjutkan studinya ke Al-Azhar, Kairo, dan kemudian mengembangkan ilmunya tersebut di tanah air. Salah satu gerakan pembaharuannya adalah mengadakan pembaruan dalam metode pengajaran bahasa Arab. (Mahmud Yunus: Pembaru Pendidikn Islam Indonesia, dalam Jurnal Madarasah, No. 02/1/1997, h. 30 
masyarakatat Minangkabau, termasuk dalam struktur sosial dan juga politik masyarakatnya, sebagai contoh dapat kita lihat bagaimana terekpresikannya ajaran Islam itu ke dalam struktur sosial-politik Minangkabau, seperti terlihat dalam implementasi konsep kekuasan yang dikenal dengan Rajo Tigo Selo, yakni Raja Alam di Pagaruyung, Raja Adat, di Buo dan Raja Ibadat di Sumpur Kudus. Masing-masing raja memiliki otoritas penuh dalam masing-masing yurisdiksinya. Pada tingkat nagari, fungsi-fungsi keagamaan tercakup dalam hirarki adat, misalnya Malim, ${ }^{30}$ salah satu dari empat funsionaris adat, mewakili aspek keagamaan dari urusan-urusan adat dalam kesempatan seperti pernikahan, perceraian, dan lain-lain. Meski otoritas Malim ini agak terkesan berasal dari jabatan warisan ketimbang dari capaian pengetahuan agama, berbeda dengan "Tuanku" yang memperoleh jabatan bukan dengan mewarisi jabatan sesuai dengan adat, melainkan dengan pengajaran agama Islam. ${ }^{31}$

Fenomena Islam di Minangkabau sangatlah menarik terutama dalam hubungannya dengan adat. Terjadi pergumulan yang cukup hebat antara agama dan adat yang terkadang membawa kepada konflik fisik. Perang Padri yang terkenal itu adalah sebuah contoh yang konkret menyangkut hal ini. Meski terdapat sekian penyebab yang menyulut terjadinya perang tersebut, faktor hubungan agama dan adat adalah faktor yang dominan.32 Akan tetapi satu hal yang tak dapat dipungkiri adalah bahwa Islam telah membumi di Ranah Minang. Dari data statistik tahun 1981 jumlah penduduk Minangkabau 3.468.825 orang. 3.404. 135 orang adalah muslim. Ini bararti hampir $100 \%$ dari penduduknya adalah pemeluk agama Islam.33

Sedemikian membuminya Islam di bumi Minangkabau sehingga mempengaruhi kepada tatanan sosial-kultural dan politik Minangkabau. Hal itu dapat dilihat dalam sistem nagari yang merupakan wilayah unit teritorial yang

${ }^{30}$ Malim, ini berasal dari kosakata bahasa Arab yang terambil dari kata Mu'allim (guru, orang yang tahu). Dalam sturuktur adat dalam nagari yang memerintah setiap suku ada yang disebut "urang ampek jinih" (orang empat jenis), yaitu, penghulu, Manti, Dubalang, dan Malim. Sementara pada tingkat Nagari, funsionaris keagamaan ialah "tuanku nan barampek", yakni, Imam, Khatib, Bilal dan Qadhi. Di samping itu disebutkan pula bahwa masyarakat nagari dipimpin oleh tiga macam unsur yang telah berpadu menjadi satu (tali tigo sapilin, tunggu tigo sajarangan) yaitu ninik-mamak, alim-ulama, cerdik-pandai. Pada tingkat kerajaan dikenal raja tigo selo, rajo Alam, rajo adat dan rajo ibadat. Di bawah raja ini, terdapat pula (dewan basa ampek balai), Tuan Kadi (Qâdhi) di Padang Gantiang, Bandaro di Sungai Tarab, Makhudum di Sumanik, dan Indomo di Suruaso. Lihat Sanusi Latief, Op.cit, h. 68-69. bandingkan dengan MD. Mansoer, Op.cit, h. 64

${ }^{31}$ Azyumardi Azra, Surau..., Op.cit, h. 45

${ }^{32}$ Bagaimana terjadinya perang Paderi itu dapat dibaca dalam Muhammad Rajab, Perang Paderi di Sumatera Barat (1803-1838), (Jakarta: Balai Pustaka, 1964), h. 10-18

${ }^{33}$ Sanusi Latief, Gerakan Taum Tua Di Minangkabau, Disertasi Doktor IAIN Syarif Hidayatullah Jakarta, 1988, tidak terbit, h. xv 
berlaku di Minangkabau. Di dalam sebuah nagari harus ada sekian fasilitas umum; seperti jalan, balai adat, sebagai tempat bagi penduduk menyatakan suaranya, pengadilan yang dapat menangi kasus-kasus hukum tertentu, lapangan terbuka untuk hiburan dan olah raga, dan juga dalam kasus tertentu, tempat pencucian umum dan lain sebagainya. Di samping itu semua, nagari juga harus memiliki sebuah majid tempat melaksanakan aktivitas-aktivitas keagamaan. Mempunyai harta kekayaan sebagaiman tercermin dalam ungkapan adat: "bacupak bagantang balimbago, batarak bakapalo koto, yakni, nagari harus memiliki fisilitas-fasilitas standar untuk penyimpanan barang-barang kering dan basah (lumbung), norma yang jelas, surau, dan pusat pemukiman. Dengan semua karakteristik di atas, setiap nagari menjadi semacam entitas politik yang "independen". Dengan kurangnya kekuasaan politik yang tersentralisasi di alam Minangkabau, nagari, dengan otonominya yang kuat, sering dikarakterisasikan sebagai "republik desa".34 Dalam konteks sosial-keagamaan pengaruh Islam juga terlihat pada terdapatnya empat orang pejabat nagari yang kegiataankegiatan mereka berpusat di Masjid, yaitu imam, khatib, bilal dan qadhi. Mereka ini merupakan pejabat-pejabat nagari yang dipilih dan diangkat oleh nagari.35

Kalau membuminya Islam dalam masyarakat Minangkabau tergambar sedemikian jelas maka pertanyaan yang muncul adalah apakah bahasa Arab juga membumi di bumi Minangkabau? Dengan kata lain, kalau bahasa Arab adalah bagian yang tidak dapat dipisahkan dengan agama Islam, maka sejauh mana pengaruh bahasa Arab ini terhadap bahasa Minangkabau?

Bahasa, pada hakikatnya, dapat diumpamakan seperti makhluk hidup. Ia dapat hidup, tumbuh, berkembang dan pada saat yang sama, mungkin akan mengalami kematian. Bahasa Arab adalah salah satu bahasa yang mampu bertahan hidup hingga saat ini. Bahasa Sangsekerta yang dulu pernah ada, pada saat ini, telah mengalami kematian. Dalam teori lingistik, setiap bahasa yang hidup pasti akan mengalamai proses akulturasi, dia akan saling berinteraksi dan saling pengaruh-mempengaruhi dengan bahasa-bahasa lainnya. Proses akulturasi (al-shirâ' al-lughawi) tersebut disebabkan oleh berbagai faktor, namun yang terpenting darinya dapat disimpulkan dalam dua hal pokok sebagai berikut; pertama, karena masuknya unsur-unsur asing ke dalam suatu komunitas negeri tertentu, baik dengan cara perang (al-harb), migrasi (hijrah), kolonialisme (istibdâd) dan lain sebagainya, dan kedua; karena adanya dua komunitas negeri yang berbeda bahasa hidup saling berdampingan, akan tetapi penduduknya

\footnotetext{
${ }^{34}$ Azyumardi Azra, Surau... Op.cit., h. 38

${ }^{35}$ Sanusi Latief, Op.cit., h. 53
} 
saling menjalin hubungan atau saling berinteraksi satu sama lain karena berbagai kepentingan.36

Setiap bahasa, termasuk bahasa Minang, akan mengalami perubahan selama bahasa itu masih hidup dan dipergunakan oleh masyarakat penuturnya. Meski sering kali perubahan itu tidak disadari oleh si penutur. Salah satu penyebab terjadi perubahan itu adalah adanya pengaruh bahasa lain. Pengaruh itu biasanya dapat dilihat dari peminjaman kosakata asing dalam bahasa itu. Peminjaman ini merupakan gejala umum dalam berbahasa. Inilah yang disebut dengan interferensi. Interferensi ini adalah akibat dari terjadinya kontak bahasa. ${ }^{37}$ Terjadinya saling serap itu adalah peristiwa umum dalam kontak bahasa. ${ }^{38}$

Tidak dapat dipungkiri, terdapat sejumlah kosakata yang berasal dari bahasa Arab dalam khazanah pembendaharaan bahasa Minangkabau. Kosakata bahasa Arab tersebut hampir terdapat di setiap pranata sosial-kultural, politik, di samping keagamaan, dalam masyarakat Minangkabau. Barangkali beberapa contoh berikut mungkin dapat medeskripsikan hal itu, seperti; kosakata sutan, sidi, malim, pakih, syaikh, abak, amak, sirawa, dan lain-lain. Secara semantik semua kosakata itu dapat menggambarkan semua lapisan sosio-kultural dalam masyarakat Minangkabau. Sutan itu berasal dari kata shulthan (bahasa Arab). Dalam bahasa Minangkabau kata sutan itu dilekatkan pada gelar seseorang yang mempunyai darah keturunan raja-raja (bangsawan)39. Demikian halnya dengan sidi, malim, pakih, syaikh (yang diserap dari bahasa Arab, sayyidi, mu'allim, faqîh, syaikh), dilekatkan kepada mereka-mereka yang dianggap mempunyai kelebihan dalam pengetahuan agama atau pemuka-pemuka agama. Sedangkan tiga terakhir, abak, amak, sirawa, (juga kata serapan dari bahasa Arab abun atau âbâ', ummun, ummahât, dan sirwâlun) adalah lafadz-lafadz yang dipergunakan dalam komunikasi sosial.

Di Minangkabau pada umumnya karena kuatnya pengaruh Islam sehingga banyak terjadi peminjaman terhadap kosakata Arab, terutama dalam laras keagamaan. Bahkan menurut Cak Nur, pada tahun-tahun permulaan kemerdekan Indonesia, di mana para kaum intelektual yang berasal dari Minangkabau mempunyai peran yang cukup besar dalam pencarian istilah-istilah

${ }^{36}$ Ali Abdul Wahid Wafi, Ilmu al-Lughah, (Kairo: Dâr Nahdhah Mashr li alThaba' wa al-Nasyr, 1940), h. 229

37 M. Anton Moeliono, Kembara Bahasa: Kumpulan Karangan Tersebar, (Jakarta: Gramedia, 1989), h. 147

${ }^{38}$ Suwito, Pengantar Awal Sosiolinguistik: Teori dan Problema, (Solo: Henary Offset, 1983), h.55

${ }^{39}$ Abdul Kadir Usman, Kamus Umum Bahasa Minangkabau-Indonesia, Padang: Anggrek Media, 2002, hal. 514 
dalam sistem kenegaraan kita. Sehingga terasa betul nuansa arabisasi itu. Berikut akan dikutipkan ulasan Cak Nur tersebut secara detil:

Pada tahun-tahun permulaan kemerdekaan nampaknya peranan bahasa Arab itu masih cukup besar. Maka kita mewarisi nama-nama seperti "Dewan Perwakilan Rakyat", "Majlis Permusyawaratan Rakyat", "Musyawarah Mufakat" dan lain-lain yang diambil dari bahasa Arab. Agaknya hal ini terjadi karena menonjolnya peranan kaum intelektual yang berasal dari Sumatera, khususnya Minangkabau. Mereka memiliki latar-belakang keislaman yang lebih kuat (atau latar-belakang budaya lokal yang lebih lemah), dan merupakan angkatan pembibit bahasa Indonesia. Tetapi setelah kaum intelektual dari Jawa sendiri juga tidak kikuk lagi berbahasa Indonesia (ingat, intelektual Jawa hasil pendidikan Belanda hanya fasih berbahasa Belanda atau Jawa, dan bahasa Melayu mereka ketahui sebagai bahasa "pasaran"). Mereka mulai menggeser peranan orang-orang Minang sebagai produsen istilah-istilah. Karena umumnya mereka berlatar-belakang budaya priyayi, maka referensi mereka adalah bahasa Sangsekerta. Maka itulah bermunculan istilah-istilah seperti; "Graha Purna Yudha", "Sasono Langen Budoyo", Sam Karya Nugraha", dan sejenisnya. (maka tidak heran ada orang yang mengatakan apa yang terjadi ini sebagai proses "Mojopahitisasi", yang kemudian menimbulkan reaksi kurang senang dari kelompok-kelompok yang tidak merasa ikut memilikinya). ${ }^{40}$

Meski contoh yang disebutkan oleh Cak Nur di atas, terjadi dalam konteks interferensi bahasa Arab dalam bahasa Indonesia, dan dengan demikian, agak terasa jauh dari pembahasan, akan tetapi justru contoh itu ditonjolkan karena ingin memperlihatkan satu hal penting menyangkut deskripsi tentang masyarakat Minangkabau. Dengan kata lain, betapa kaum intelektual yang berasal dari Minangkabau, karena keterpengaruhannya yang begitu kuat dengan Islam maka kemudian mereka mencarikan istilah-istilah dari bahasa Arab untuk keperluan-keperluan kenegaraan, sehingga mereka dikenal waktu itu sebagai produsen istilah-istilah Arab. Selain itu, bahasa Minangkabau sebagai bahasa daerah, tidak diragukan lagi mempunyai andil yang tidak kecil pula dalam membangun bahasa Nasional ini. ${ }^{41}$

Unsur Islam, dengan bahasa Arabnya, adalah sebagai faktor asing yang terpenting dalam proses terjadinya kontak bahasa di Minangkabau. Sebagaimana telah kita ketahui bersama bahwa pada awal abad ke-19 telah pulang tiga orang

${ }^{40}$ Baca tulisan Nurcholish Madjid, Al-Qur'an, Kaum Intelektual dan Kebangkitan Kembali Islam, dalam Rusydi Hamka (Ed), Kebangkitan Islam Dalam Pembahasan, (Jakarta: Yayasan Nurul Islam, 1979), h. 110-111

41 Yuliana AS, Bahasa Minangkabau di Perguruan Tinggi, makalah yang dipresentasikan pada Seminar Dialetologi, Tugu, PPPB, 1977, h. 4. bandingkan juga dengan Syamsir Arifin, Dialek Padang..., Op.cit., h. 1 
ulama Minang dari pusat agama Islam, Mekkah dan Madinah, yang kemudian melahirkan "gerakan revolusi keagamaan" di Minangkabau. Salah satu diantara mereka adalah H. Sumanik yakni putra Tanah Datar Luhak Nan Tuo. Kemudian pada penghujung abad ke-19 awal abad ke-20 pulang pula empat orang ulama Minangkabau, yakni Jamil Jambek, Abdullah Ahmad, Abd Karim Amrullah dan M. Thaib Umar, yang kemudian dikenal dengan ulama kaum muda, yang terakhir yakni, Muhammad Thaib Umar adalah berasal dari daerah ini dan berjuang mengembangkan ajaran Islam di sini. Sebagaimana diceritakan oleh Mahmud Yunus bahwa M. Thaib Umar ini telah mendirikan madrasah di Surau Tanjung Pauh yang diberi nama Madras School. ${ }^{42}$ Di sekolah inilah Mahmud Yunus, seorang putra Tanah Datar yang kemudian terkenal sebagai orang pertama yang mengadakan reformasi metode pengajaran Bahasa Arab di tanah air.

Dengan terserapnya Islam ke dalam kehidupan masyarakat Minangkabau, maka dengan sendirinya bahasa Arab pun terserap pula ke dalam bahasa Minangkabau. Kata-kata atau terma-terma Islam yang tidak terdapat dalam khazanah bahasa Minangkabau dengan sendirinya diserap oleh bahasa ini setelah terlebih dahulu mengalami proses "minangisasi" yakni proses penyesuaian bunyi (fonologi) dan morphologi dengan bahasa Minangkabau. Di samping contoh-contoh yang telah disebutkan sebelum ini, berikut kita ambil contoh lainnya, misalnya istilah faqîh yang jelas berasal dari bahasa Arab, yakni berkaitan dengan istilah fiqh, yang aslinya berarti orang yang mempunyai pengetahuan atau pemahaman atas sesuatu. ${ }^{43}$ Kemudian dengan melalui proses yang saya sebut dengan istilah "minangisasai" maka kata itu berobah menjadi pakiah, yang dalam bahasa Minangkabau berarti; 1. seseorang yang ahli dalam ilmu hukum agama, 2. sebagaimana umum dikenal masa lalu untuk guru-guru mengaji di surau. ${ }^{44}$

Sebenarnya, kata fiqh pada awalnya sinonim dari kata ilm seperti kata fiqh al-lughah tetapi kemudian pengertiannya menyempit kepada pengetahuan agama ('ilm al-dîn), hukum Islam (syarỉah) dan akhirnya pada detail-detail yang berasal dari yang terakhir (furu). Jadi, faqî̉ berubah artinya dari seseorang yang

${ }^{42}$ Mahmud Yunus, Riwayat Hidup Prof. Dr. H.Mahmud Yunus, (Jakarta: PT. Hadikarya Agung, t.th), h. 10-11

${ }^{43}$ Lihat kamus-kamus Bahasa Arab antara lain, Abu Luweis Ma'luf al-Yusu'i, alMunjid fi al-Lughah wa al-A'lâm, (Bairut: Dar El-Machreq, 1988), h. 591. Lihat juga misalnya, Ahmad Walson Munawir, Al-Munawwir, Kamus-Indonesia Arab, (Yogyakarta: Pondok Pesantren “al-Munawwir”, 1984), h. 1147

${ }^{44}$ Abdul Kadi Usman, Kamus Umum Bahasa Minangkabau-Indonesia, (Padang: Anggrek Media, 2002), h. 427 
memahami menjadi seorang ahli teologi, kemudian syar̂ah dan akhirnya, ahli dalam fiqh yang sering sangat kasuistik. ${ }^{45}$

Di Minangkabau, di samping istilah faqîh ini, terdapat lagi istilah-istilah lain untuk merujuk kepada orang-orang yang "mengaji" di surau, seperti urang siak, faqîr. Ketiga istilah itu, faqîh, urang siak, dan faqîr lebih umum digunakan ketimbang istilah "murid" untuk merujuk kepada orang yang belajar di surau, terutama setelah usainya perang Paderi. Istilah "murid” kelihatannya baru belakangan yang acap kali digunakan untuk orang yang belajar di sekolah system Barat maupun di madrasah. Sementara itu, istilah faqîr, pada mulanya berarti orang yang sangat membutuhkan, baik materil maupun sprituil. Istilah ini berbeda dengan pengemis, atau peminta-minta (sâ'il), istilah ini lebih kental nuansa sufistiknya.

Kalau contoh di atas mempresentasikan bentuk interferensi dalam laras keagamaan maka contoh kata serapan berikut mempresentasikan bentuknya dalam laras sosio-politik, sebutlah misalnya kata yang sangat populer "musyawarab-mufakat" (musyawarob-mufakék). Di dalam masyarakat Minangkabau musyawarah-mufakat itu sangat penting. Sehingga terkenal dalam ungkapan adat:

Kamanakan barajo ka mamak

Mamak barajo ka panghulu

Panghulu barajo ka mufakat

Mufakat barajo ka kabanaran

Kabanaran berdiri sendiri

Masyarakat Minangkabau tidak mengenal sistem suara terbanyak atau mayoritas atau $50 \%$ plus 1 , atau berdasarkan sistem formatur, dan lain sebagainya, sebagaimana dikenal dalam sistem demokrasi modern sekarang. Bagi mereka "kok bulek bulih digolongkean, kok picak bulib di layangkan". (kalau bulat bisa digulirkan, jika pipih sudah bisa dilayangkan". Itulah makna mufakat bagi mereka.

\section{Penutup}

Demikianlah terlihat jelas bagaimana bahasa Arab telah terserap sedemikian rupa ke dalam khazanah bahasa Minangkabu. Berdasarkan penelitian penulis, terdapat 726 lebih kata-kata dari bahasa Arab yang telah terserap ke dalam bahasa Minangkabau. Jumlah tersebut ditemukan setelah menghitung satu persatu (manual) semua kosakata yang ada dalam kamus bahasa Minangkabau. Penghitungan ini dilakukan hanya kepada sebuah kamus Bahasa Minangkabau yang tulis oleh Abdul Kadir Usmas, dengan menghitung kata-kata

\footnotetext{
${ }^{45}$ Azyumardi Azra, Surau... Op.cit., h. 96
} 
yang berkode (A) yang diberikan oleh pengarangnya di belakang setiap kosakata tersebut. Menurut penulis, jumlah itu sebenarnya akan lebih banyak lagi jika saja dimasukkan juga kata-kata yang telah populer di kalangan masyarakat Minangkabau tetapi tidak diberi kode (A) oleh pengarang kamus tersebut. Misalnya, kata-kata Abak, amak, sirawa dan lain-lain, yang sesungguhnya juga berasal dari bahasa Arab namun tidak diberi kode (A) oleh pengarangnya di belakang kata itu. 


\section{Daftar Pustaka}

al-Atsir, Ibn, Al-Kâmil fi al-Târîkh, Bairut: Dâr al-Sader, 1965

al-Samirra'i, Ibrahim, Fiqh al-Lughah al-Muqâran, Bairut: Dar al-Ilmi Li alMalayin, 1987

AS, Yuliana, Bahasa Minangkabau di Perguruan Tinggi, makalah yang dipresentasikan pada Seminar Dialetologi, Tugu, PPPB, 1977

Azra, Azyumardi, Jaringan Ulama Timur Tengah dan Kepulauan Nusantara Abad XVII dan XVIII: Melacak Akar-akar Pembaruan Pemikiran Islam di Indonesia, Bandung: Mizan, 1995 , Surau: Pendidikan Islam Tradisional Dalam Transisi dan

Modernisasi, Jakarta: Logos Wacana Ilmu, 2003

Beeston, A.F.L, The Arabic Language Today, London:Huchinso \& Co, 1970

Dobbin, Christine, Islamic Revivalism In Changing Peasant Economy Central Sumatera, 1774-1848, London: Curson Press Ltd, 1983

Hamka, Ayabku: Riwayat DR. H. Amrullah dan Perjuangan Kaum Agama di Sumatera, Jakarta: Umminda, 1982 , Sedjarah Islam di Sumatera, Medan: t.p., 1950 , Minangkabau Dengan Islam, Bukittinggi: t,p., 1929 , Muhammadiyah di Minangkabau, Jakarta: t, p., 1974

Ja'kub, Ismail, Sejarah Islam Di Indonesia, Djakarta: t.p, 1956

Madjid, Nurcholish, Islam Doktrin dan Peradaban: Sebuah Telaab Kritis Tentang Masalab Keimanan, Kemanusian dan Kemodernan, Jakarta: Yayasan Wakaf Paramadina, 1995 , Al-Qur'an, Kaum Intelektual dan Kebangkitan Kembali Islam, dalam Rusydi Hamka (Ed), Kebangkitan Islam Dalam Pembahasan, Jakarta: Yayasan Nurul Islam, 1979

Mansoer, MD. Dkk, Sejarah Minangkabu, Jakarta: Bhratara, 1970

Moeliono, M. Anton, Kembara Bahasa: Kumpulan Karangan Tersebar, Jakarta: Gramedia, 1989

Nasution, Harun, Islam Ditinjau Dari Berbagai Aspeknya, Jakarta: UI Press, 1985 Jakarta: Bulan Bintang, 1975

Rajab, Muhammad, Perang Paderi di Sumatera Barat (1803-1838), Jakarta: Balai Pustaka, 1964

Sanusi Latif, Gerakan Kaum Tua Di Minangkabau, Jakarta: Disertasi IAIN Jakarta, 1988

Shihab, Muhammad Quraish, Mukjizat al-Qur'an: Ditinjau Dari Aspek Kebahasaan, Isyarat Imiah dan Pemberitaan Gaib, Bandung: Mizan, 2003

Suwito, Pengantar Awal Sosiolinguistik: Teori dan Problema, Solo: Henary Offset, 1983

Usman, Abdul Kadir, Kamus Umum Bahasa Minangkabau-Indonesia, Padang: Anggrek Media, 2002 
138 | Arabiyatuna: Jurnal Bahasa Arab, Vol. 1, No. 2, 2017

Wafi, Ali Abdul Wahid, Ilmu al-Lughah, Kairo: Dâr Nahdhah Mashr li al-Thaba' wa al-Nasyr, 1940

Yunus, Mahmud, Riwayat Hidup Prof. Dr. H.Mahmud Yunus, Jakarta: PT. Hadikarya Agung, t.th 